\title{
INTRODUCTION
}

\section{Jürgen Habermas and education}

\section{TOMAS ENGLUND}

The German social philosopher Jürgen Habermas has had an enormous impact on the ways in which scholars examine a range of societal issues. His early works on the public sphere and on knowledge and human interests are in the critical tradition of the Frankfurt school, but later he took a linguistic and pragmatic turn. His two-volume masterpiece on The Theory of Communicative Action (Habermas 1984, 1987a) and his The Philosophical Discourse of Modernity (Habermas 1987b), and his Moral Consciousness and Communicative Action (Habermas 1990) have created what might be called the preconditions for a paradigm shift on rationality. Moving from a philosophy of consciousness towards a philosophy of language and communication and the theories of procedural communicative rationality, and later to discourse theory and deliberative democracy, he has positioned himself as a defender of modernity - but a modernity of a certain kind. Habermas' position implies a critical view of the characteristics of classical modernity with its technological rationality and colonization of the life-world.

Habermas' position also implies a critical stance on post-modern refutations of all kinds of rationality as expressions of power. Habermas contends that the project of modernity can be seen as unfinished, and that, through communicative action, an on-going normative rationalization is possible. The theory of communicative action that he develops is, thus, a theory of social integration. His sources of inspiration include the inter-subjectivist theoretical framework elaborated by the classic US pragmatist George Herbert Mead (Heath 2001), speech-act theory, further developed by Habermas into a universal pragmatics, Durkheim's theory on social order, further elaborated into Habermas' theory on normative validity, and so on. In some of his later works, in, for example, Between Facts and Norms (Habermas 1996) and Truth and fustification (Habermas 2003), he has further developed his discourse ethics into the idea of a self-regulating community of law based on free and equal citizens, and returned to the implications of

Tomas Englund is a professor of education in the Department of Education, Örebro University, S-701 82 Örebro, Sweden; e-mail: tomas.englund@pi.oru.se. His research interests centre on curriculum theory and didactics, curriculum history, political socialization and citizenship education, and the philosophical aspects of education. He directs the research group 'Education and Democracy' and is co-editor of the Swedish journal with the same name (in Swedish, Utbildning \& Demokrati). His most recent book is Skillnad och konsekvens [Difference and consequences] (Lund, Sweden: Studentlitteratur, 2004). 
the theory of communicative action for epistemology and metaphysics by relating it to Putnam's (2002) notion of internal realism.

There are real differences in the styles of writing of the classical pragmatist John Dewey and Jürgen Habermas as the pragmatist of late modernity, but both emphasize (at least in the late phases of their writing) the socially integrative force and constitutive power of communication. In that sense, each of them develops a kind of social philosophy that may be seen as a general theory of education. They also offer a similar view of a deeper, deliberative democracy, believing that 'the essential need ... is the improvement of the methods and conditions of debate, discussion and persuasion' (Habermas 1996: 304, with reference to Dewey 1988). In Dewey's original text, the sentence Habermas quoted continues: 'that is the problem of the public' (Dewey 1988: 365), while Habermas (1996: 304) states more precisely:

Deliberative politics acquires its legitimating force from the discursive structure of an opinion- and will-formation that can fulfil its socially integrative function only because citizens expect its result to have a reasonable quality.

Through his theoretical framework, Habermas provides some basic starting points for an analysis of the relationship between society and education, especially within his perspective of normative rationalization (Englund 2000). However, the implications for education can be interpreted in different ways (Coulter 2001). The following series of papers attempts to make use of the later works of Habermas in the field of education in order to pursue these implications. The theme in the first paper, by Englund, is that of deliberative communication as a central form of activity in schools from within the perspective of Habermas' theory of normative rationalization. The second paper by Carleheden presents, interprets, and discusses the theory of normative transformation that can be found in Habermas' theory of law and democracy, supplemented with a comparison of Habermas' (1996) three paradigms of law and the three educational conceptions developed by Englund (1986, 1996). The third paper, by Boman, discusses the normative conditions of education that can contribute to the development of a political culture with a plurality of forms of life. The fourth paper, by Roth, on post-national education, argues that global transformation is challenging the conventional use of national education, and analyses the implications of this claim.

\section{References}

Coulter, D. (2001) Teaching as communicative action: Habermas and education. In V. Richardson (ed.), Handbook of Research on Teaching, $4^{\text {th }}$ edn (Washington, DC: American Educational Research Association), 90-98.

Dewey, J. (1988 [1927]) The public and its problems. In J. Dewey (ed.), The Later Works, 1925-1953: Volume 2: 1925-1927, ed. J. A. Boydston (Carbondale, IL: Southern Illinois University Press), 235-372.

Englund, T. (1986) Curriculum as a Political Problem. Changing Educational Conceptions with Special Reference to Citizenship Education Uppsala Studies in Education 25 (Lund, Sweden: Studentlitteratur).

Englund, T. (1996) The public and the text. Fournal of Curriculum Studies, 28(1), 1-35. 
Englund, T. (2000) Rethinking democracy and education: towards an education of deliberative citizens. Fournal of Curriculum Studies, 32(2), 305-313.

Habermas, J. (1984 [1981 in German]) The Theory of Communicative Action: Vol. 1: Reason and the Rationalization of Society, trans. T. McCarthy (Boston, MA: Beacon Press).

Habermas, J. (1987a [1981 in German]) The Theory of Communicative Action: Vol. 2: Lifeworld and System: A Critique of Functionalist Reason, trans. T. McCarthy (Boston, MA: Beacon Press).

Habermas, J. (1987b [1985 in German]) The Philosophical Discourse of Modernity: Twelve Lectures, trans. F. Lawrence (Cambridge: Polity Press).

Habermas, J. (1990 [1983 in German]) Moral Consciousness and Communicative Action, trans. C. Lenhardt and S. W. Nicholsen (Cambridge, MA: MIT Press).

Habermas, J. (1996 [1992 in German]) Between Facts and Norms: Contributions to a Discourse Theory of Law and Democracy, trans. W. Rehg (Cambridge: Polity Press).

Habermas, J. (2003 [1999 in German]) Truth and Fustification, trans. B. Fultner (Cambridge, MA: MIT Press).

Heath, J. (2001) Communicative Action and Rational Choice (Cambridge, MA: MIT Press).

Putnam, H. (2002) The Collapse of the Fact/Value Dichotomy and Other Essays (Cambridge, MA: Harvard University Press). 
Copyright of Journal of Curriculum Studies is the property of Routledge and its content may not be copied or emailed to multiple sites or posted to a listserv without the copyright holder's express written permission. However, users may print, download, or email articles for individual use. 